was thereby revived in a new form. Yet where has it led us ? To a slightly better understanding of the laws governing development, but also to obstacles which defy further progress in the present state of our knowledge. For the moment, zoologists have exhausted the subject and await the arrival of a new idea. Some even deny the validity of the organiser theory, and it is possible that much of the work that has been done may be relegated historically to one of those attractive side avenues in science which forms a pleasant rendezvous for a while but is destined to be neglected later because it leads nowhere.

\section{Teaching of Statistics}

Is a paper read to the Royal Statistical Society on June 20, 1939, and printed, with the ensuing diseussion, in its Journal (102, 532 ; 1939), Dr. John Wishart pointed out, among other things necessary for the progress of the subject, the urgent need for a standard treatise on its mathematical side. There are many text-books on practical statistical methods, usually restricted to one particular field of application, such as economics, business statistics, psycho$\operatorname{logy}$, or biology and medicine, in which the reader has to accept the statements without proof. If a mathematical student asks where these proofs may be found, he may be told "You must look up the original papers, which you will not be able to understand". It is urgently necessary that a text-book should be produced to end this unsatisfactory state of affairs.

Dr. Wishart discussed in some detail what such a text-book should contain, and feared that it was beyond the powers of any one man to produce; he favoured a co-operative venture. However, many will differ from Dr. Wishart on this point, and prefer the incompleteness which may be found in the work of a single writer to the lack of unity characteristic of a book produced by a committee. In the interests of science it is desirable that we should not have to wait indefinitely until the ideal treatise can be produced. Let someone have the courage to make the attempt now ; there is no one better qualified for the task than Dr. Wishart himself.

\section{Meteorology in Southern Rhodesia}

THE meteorological report of the Department of Agriculture, Southern Rhodesia, for the year ended June 30, 1938, covers the period during which the Northern Rhodesia Weather Service was taken over from the British East Africa Meteorological Service by arrangement with the Governments concerned. After the transfer, the establishment of a new air route in Northern Rhodesia was announced by the Government of that country to replace the existing route via Broken Hill and Mpika, and this led to the setting up of a first-order meteorological station at Lusaka, while arrangements were made to open another at Kasama later. Civil aviation developed to twice its initial volume during the period in Southern Rhodesia, and the Service found it difficult to meet the increased demands for weather reports.
The formula used for the previous ten years for forecasting the seasonal rainfall gave a prediction of abundant rainfall for 1938-39, with a result that could not of course be indicated at the time of completion of this report. The only previous comparable prediction of abundant rainfall was for 1934-35, and was the most conspicuous of only three failures out of the previous nine predictions to forecast whether the rainfall would be above or below the average. On one of these three occasions the predicted and actual departures were so small that it can reasonably be regarded as a successful forecast, making the successes nearly eighty per cent, which is a very satisfactory result. It is stated that the predictions have proved of value, as may easily be credited in view of this high percentage. The report, as usual, includes extensive meteorological tables for a large number of stations for the year, among them those giving hourly values of several items for Salisbury Observatory.

\section{Mistletoe, Magic and Medicine}

THE October issue of the Bulletin of the History of Medicine contains an excellent survey by Dr. Leo Kanner, of Baltimore, of the history of mistletoe from the earliest times until the present day. The magic virtues formerly attributed to it were as follows: it was regarded as a promoter of grain and fruit harvests ; a fattener of live-stocks ; an incentive to milk production; a safeguard against ghosts and witches, nightmares and conflagrations ; a bringer of luck to farmers, home owners, hunters, warriors, wrestlers and travellers ; an agent which forces spirits to reveal their secrets; a discoverer of buried treasures, and a feeder of the mystic mandrake. It was also characteristic of its magic powers that mistletoe was regarded as a panacea, as it was used for the prevention and cure of plague, leprosy, fevers, syphilis, consumption, hæmorrhages, diseases of the heart and lungs, intestinal disorders, poór appetite, skin affections, nervous troubles and, most of all, epilepsy.

On the other hand, mistletoe was sometimes regarded as a baleful plant and was supposed to possess poisonous properties for which numerous remedies were prescribed by Galen and others. In the first half of the nineteenth century all the therapeutic properties of the mistletoe had become discredited, and it was not until 1906 that it became permanently established as a useful drug for the treatment of hypertension and later as a diuretic and styptic.

\section{Tests of a 4,000 kw. Gas-Turbine Set}

Prof. A. Stopora, in Engineering of January 5, gives a description and test results of a $4,000 \mathrm{kw}$. combustion-turbine generating set, recently constructed by Messrs. Brown, Boveri and Co., Ltd., of Baden, Switzerland, for the city of Neuchâtel. The set was built for installing in a bomb-proof chamber for use in emergencies, and consists of an axial-type air-compressor, a combustion chamber, a 
gas-turbine exhausting direct to the atmosphere, and an electric generator. "The present-day possibilities of realising a successful gas-turbine, resulting from the improvement of the compressor efficiency on the one hand, and the availability of heat resisting materials on the other hand, would have appeared unthinkable but a short time ago."

When the set is working, with the temperature of the atmosphere about $77^{\circ} \mathrm{F}$, air from the compressor is discharged at a pressure of about $60 \mathrm{lb}$. per sq. in. and a temperature of nearly $400^{\circ} \mathrm{F}$. to the combustion chamber. The fuel is gas oil. Only a part of the air is used for combustion, the remainder being used to bring down the temperature of the burnt gases to about $1,000^{\circ} \mathrm{F}$., at which temperature they enter the turbine. After doing work in the turbine, the gas is exhausted to the atmosphere at a temperature of about $500^{\circ} \mathrm{F}$. The set is rated at 4,000 kw., and revolves at 3,000 r.p.m., producing three-phase current at 50 cycles. The thermal efficiency is $17 \cdot 38$ per cent. The gas turbine, says Prof. Stodola, has many promising possibilities which merit the attention of prime-mover designers and of leaders of industry.

\section{Swiss Watch-making Industry}

IN Swiss Technics, published by the Swiss Office for the Development of Trade, in Zurich and Lausanne, during November-December 1939, it is stated that although less trade was carried out during the first few months of the year than during the corresponding months of 1938 there was decided improvement in the summer, so that exports to most foreign countries very nearly reached the 1938 figures. This progress would certainly have been maintained had it not been for the War. It would be absurd to give way to despondency with regard to the future of the Swiss watch-making trade. There are two good reasons for looking forward hopefully. The first is the great improvements made by the industry in perfecting watches during the last ten years. The improvements have been continuous.

The 1939 steel watch is proof against fall, shock and damp. It is antimagnetic and does not oxidize. It unites a number of advantages and improvements not found in the best watches made before the War of 1914-18. The manufacturers are not afraid of losing their customers. As an example they give Great Britain, where the demand is increasing owing to the greater need for punctuality. The second reason lies in the organization of the Swiss watch-making industry. The watches are made of good materials and with great technical skill. Quite poor people will always find good watches at a price suited to their purses. Competition which the Swiss might justly have feared has now disappeared. They are therefore prepared to provide the world with the three types of watches produced by a trade that is built up on sound principles: chronometers and precision instruments, suitable for observatories, beautiful high grade watches, and cheaper watches which nevertheless keep good time. It is thus that the Swiss industry faces the great crisis.

\section{Earth Tremors in Belgium}

ON January 7 two earthquake tremors were distinctly felt in the district immediately to the east of Mons, one at about 4.30 p.m. and the other at about 8.30 p.m. These were recorded at the Uccle Observatory at 4.29 p.m. and 8.32 p.m. respectively and the epicentre appears to have been near latitude $50^{\circ} 26^{\prime} \mathrm{N}$., longitude $4^{\circ} 0^{\prime} \mathrm{E}$. No damage or casualties are reported. It will be remembered that a much stronger earthquake did damage to property and caused injury to ten people in Belgium on June 11, 1938 (Nature, 144,950 ; 1939). On that occasion the epicentre was determined by the chief of the Belgian Seismological Service, Dr. O. Somville, to have been between Audenarde and Renaix, latitude $50^{\circ} 47^{\prime}$ N., longitude $3^{\circ} 35^{\prime} \mathrm{E}$. The 1940 epicentre thus appears to have been a little to the south and east of the 1938 epicentre, though any connexion between them is doubtful. The 1938 earthquake had a depth of focus of $45 \mathrm{~km}$. though the 1940 one may have been superficial.

\section{Development of Moscow}

A BOOKLET recently issued in Moscow entitled "Moscow in Figures" (London: Russia To-day Press Service) shows the development of the Soviet capital in recent years. According to the figures given, during the last thirteen years the population of Moscow has more than doubled, at present numbering 4,137,000. Moscow is now the third largest city in the world. The number of workers and employees in the factories and institutions of Moscow in 1939 reached 2,300,000, as against 600,000 in 1913 . In 1938 there were 117,200 births in Moscow. The city has 175 scientific research institutions in which 9,000 scientific workers are engaged. The higher educational institutions of Moscow have, 95,000 students. During the last four years 350 new schools have been built. The number of pupils at present attending the Moscow schools is 608,300 .

\section{Hygiene in South China}

THE November issue of the Bulletin de l'Office d'Hygiène Publique contains an account by InspectorGeneral Dr. A. Lasnet, the delegate of Algeria, of a sanitary mission sent by the Health Section of the Jeague of Nations to South China in December 1937, six months after the onset of the war between China and Japan. The work of the mission consisted in (1) a campaign against infectious diseases, especially smallpox during the cold season, cholera during the hot season and malaria in the spring and summer; (2) wholesale destruction of insanitary houses, construction of wide sunny streets, proper disposal of excreta, and protection of the water supply; (3) education of the population in hygiene.

\section{Detection of Toxic Gases}

Leaflets 8 and 9 of "Methods for the Detection of Toxic Gases in Industry", published by the Department of Scientific and Industrial Research 